\title{
Perbandingan Sensitivitas Empat Macam Primer untuk Deteksi Trypanosoma evansi pada Hewan yang Diinfeksi Secara Buatan dan Alami dengan Polymerase Chain Reaction \\ (Comparative Sensitivity of Four Different Primers for Detec tion of Trypanosoma evansi Infection in Experimental and Naturally Infected Animals by Polymerase Chain Reaction)
}

\author{
Sawitri DH, Wardhana AH \\ Balai Besar Penelitian Veteriner, Jl. R.E. Martadinata No 30, Bogor \\ dyah.haryuningtyas@gmail.com
}

\begin{abstract}
Trypanosoma evansi is a hemoflagella parasite as an agent of Surra's disease which causes high economic loss and death. Sensitivity of tree different sets of Trypanosoma evansi specific primers ITS-1 (480 bp), ESAG 6/7 (741 bp), TBR 1/2 (164 bp) dan TR 3/4 (257 bp) was evaluated by targeted amplification by polymerase chain reaction using $T$. evansi-infected mice blood serial dilutions and blood samples from cow and buffaloes in the field. A total of 41 samples of cow and buffaloes blood from the endemic area of Surra were tested with a Microhematocrit Centrifugation Test (MHCT) and thin blood Smear with Giemza staining (TBS) and then tested by PCR on 4 types of primers. The results showed that PCR was more sensitive than the two conventional tests (MHCT and TBS). Primer TR $3 / 4$ is the most sensitive primer followed by TBR $1 / 2$ which is able to detect $T$. evansi at detection limits $<10$ and $<3$ blood parasites/mL; ESAG 6/7 and ITS have a detection limit of 10-100 parasites / mL blood of mice each. PCR results in fields samples with 4 primary types of buffalo blood and cattle from Lebak district,also showed different sensitivity : ITS-1 > ESAG 6/7 > TBR 1/2; > TR 3/4 was detected $14.6 \% ; 19.5 \% ; 34.1 \%$; and $48.6 \%$ positive samples of $T$. evansi respectively. Primer TR 3/4 can be used routinely for surveillance and epidemiological studies of surra in endemic areas for early detection of resevoar animals in the acute, sub-acute and chronic stages.
\end{abstract}

Key words: Trypanosoma evansi, primer, ITS-1, ESAG 6/7, TBR 1/2, TR 3/4, PCR, detection

\begin{abstract}
ABSTRAK
Trypanosoma evansi merupakan parasit hemoflagella sebagai agen penyakit Surra yang menyebabkan kerugian ekonomi yang tinggi serta kematian. Sensitivitas 4 set primer spesifik terhadap Trypanosoma evansi yaitu ITS-1 (480 bp), ESAG 6/7 (741 bp), TBR 1/2 (164 bp) dan TR 3/4 (257 bp) dievaluasi dengan target amplifikasi PCR menggunakan pengenceran bertingkat darah mencit yang diinfeksi T. evansi dan darah sapi/kerbau dari lapang. Sebanyak 41 sampel darah sapi dan kerbau dari daerah endemis Surra diuji dengan Mikrohematokrit Centrifugation Test (MHCT) dan Apus darah tipis dengan pewarnaan giemza (ADG) selanjutnya diuji dengan PCR terhadap 4 macam primer tersebut. Hasil penelitian menunjukkan bahwa PCR lebih sensitif dibandingkan dengan dua uji konvensional (MHCT dan ADG). Primer TR 3/4 merupakan primer paling sensitif diikuti TBR 1/2 yaitu mampu mendeteksi $T$. evansi pada limit deteksi $\leq 10$ dan $\leq 3$ parasit /mL darah; ESAG 6/7 dan ITS-1 masing masing mempunyai limit deteksi 10-100 parasit /mLdarah mencit. Hasil PCR dengan 4 jenis primer terhadap darah kerbau dan sapi asal kabupaten Lebak, Banten juga menunjukkan sensitivitas yang berbeda yaitu dari yang terendah-tertinggi: ITS-1, ESAG 6/7,
\end{abstract}


TBR 1/2 dan TR 3/4 masing-masing mendeteksi 14,6\%; 20\%; 34,1\%; dan 48,5 \% sampel positif T. evansi. Primer TR 3/4 dapat digunakan secara rutin untuk surveillance dan studi epidemiologi surra pada daerah endemis untuk deteksi dini hewan resevoar baik pada tahap akut, sub akut maupun kronis.

Kata kunci: Trypanosoma evansi, primer, ITS-1, ESAG 6/7, TBR 1/2, TR 3/4, PCR, deteksi

\section{PENDAHULUAN}

Trypanosoma evansi sebagai agen penyebab Surra dapat menginfeksi berbagai spesies hewan termasuk hewan ternak (kuda, unta, sapi, kerbau), hewan liar (badak, gajah) dan hewan kesayangan (anjing) (Terrestrial Manual 2012). Di daerah endemis infeksi oleh parasit ini pada sebagian besar ternak jarang terdeteksi akibat gejala klinisnya yang non spesifik dan tidak cukup khas (Luckins 1992; Juyal et al. 2005). Penyakit ini merupakn salah satu penyakit penting di negara berkembang seperti Indonesia yang hampir seluruh wilayahnya merupakan daerah endemis Surra. Surra masuk dalam kategori penyakit menular strategis di Indonesia berdasarkan Keputusan Menteri Pertanian tahun 2012.

Deteksi parasit pada darah secara langsung pada hewan yang terinfestasi merupakan uji diagnostik yang digunakan sebagai Gold standart pengujian Surra (Kundu et al. 2013). Namun demikian teknik parasitologi konvensional seperti Microhematokrit centrifugation test (MHCT) dan Ulas darah tipis dengan pengecatan giemza (UDT) sering kurang sensitif terutama jika jumlah parasit dalam darah yang relatif kecil karena adanya periode prepatent atau periode relaps pada infeksi kronis (Singla et al. 2013). Teknik berbasis imunologis (Enzyme Linked Immunosorbent Assay, CATT/T.evansi dan Immuno Fluorescent Antibody Technique) sangat baik untuk screening studi epidemiologi skala besar (Greiner et al. 1997) tetapi tidak cukup sensitif untuk mendeteksi dan membedakan antara infeksi saat ini atau infeksi sebelumnya sehingga seringkali mengarah ke hasil positif palsu (Desquesnes \& Tresse 1996). Menurut Holland et al. 2001; Desquesnes \& Dávila 2002) untuk mendeteksi berbagai macam spesiesTrypanosoma pada sejumlah pejamu, teknik PCR dilaporkan lebih sensitif dibandingkan teknik konvensional parasitologi.

Surveilance infestasi penyakit surra merupakan salah satu upaya yang dilakukan untuk antisipasi, pengendalian dan mencegah terjadinya wabah Surra di daerah endemis. Untuk tujuan tersebut diperlukan implementasi metode diagnostik yang sensitif, spesifik dan reliable. Walaupun PCR telah dilaporkan merupakan salah satu metode diagnosis yang sensitif tetapi faktor yang mempengaruhi sensitivitasnya perlu diperhitungkan untuk menginterpretasi hasilnya. Salah satu yang sangat berperan untuk meningkatkan sensitivitas PCR adalah design primer dan target gen (Pruvot et al. 2013). Variasi sensitivitas dan spesifitas pada diagnosis dengan PCR tergantung pada jenis primer yang digunakan (Njiru et al. 2005; Ahmed et al. 2013). Disamping itu sensitivitas PCR juga sangat dipengaruhi oleh ekstraksi DNA dan metode preparasi sampel (Pruvot et al. 2013). Beberapa primer yang sering digunakan untuk deteksi T. evansi adalah ESAG 6/7, ITS-1, TBR 1/2, TR 3/4, Rotat 1,2 VSG (Masiga et al. 1992; Wuyts et al. 1994; Isobe et al. 2003; Njiru et al. 2005).

Internal transcribed spacer one (ITS-1) merupakan DNA ribosomal yang diketahui cocok sebagai target gen untuk deteksi beberapa spesies trypanosoma dalam satu reaksi PCR. Lokasi ITS terletak antara sekuen berulang 18S, 5.8S, and 28S gen RNA ribosomal (Barghash et al. 2014). Menurut Salim et al. (2011) panjang produk PCR ITS-1 secara spesifik berkorelasi dengan masing-masing spesies trypanosoma yaitu: T. congolense 700 
bp; T. simiae 400 bp; T. vivax 250 bp; sedangkan untuk T. evansi dan subspesies $T$. brucei sebesar 480 bp. Expression-site-associated gene (ESAG) merupakan open reading frame (ORF) Gen VSG yang masing-masing ESAG berulang pada genom (Kooter et al. 1987). Gen ini mengkode Reseptor transferin di daerah VSG yang digunakan oleh $T$. evansi mengambil FE dari pejamu (Schell et al. 1991; Kabiri \& Steverding 2001). Primer TBR 1/2 digunakan untuk mengamplifikasi sekuen berulang dari DNA mini satelit kromosom sepanjang 164 bp adalah merupakan set primer pertama yang sebagian besar digunakan untuk mendeteksi DNA trypanozoon (Masiga et al. 1992). Menurut Pruvot et al. (2010) primer TBR1/2 ini merupakan primer standar emas pengujian untuk deteksi DNA trypanozoon dengan PCR. TR 3/4 merupakan sekuens repetitive nukleotida $T$. evansi dengan homologi 93-99\% pada spesies $T$. evansi yang diuji dengan analisis phylogenetik dan molekuler (Barghash \& Darwish 2016).

Untuk mengoptimalkan diagnosis dengan PCR, salah satunya perlu mempertimbangkan faktor yang memengaruhi sensitivitasnya yaitu jenis primer yang digunakan (Sharma et al. 2013). Walaupun Primer PCR menunjukkan spesifisitas yang tinggi tetapi sensitivitasnya pada saat diterapkan pada sampel lapangan sering lebih rendah dari yang diharapkan (Masake et al. 2002). Penelitian bertujuan untuk mengevaluasi sensitivitas PCR untuk mendeteksi DNA T. evansi menggunakan empat primer berbeda.

\section{MATERI DAN METODE}

\section{Infeksi dan penghitungan T. evansi pada mencit}

Sebanyak 2 ekor mencit DDY digunakan dalam penelitian ini. Satu ekor mencit diinfeksi dengan T. evansi isolat Banten (Lbk 376) yang diperoleh dari Bblitvet Culture Collection. Satu ekor mencit tidak diinfestasi. Tingkat parasitemia dievaluasi setiap hari. Penghitungan parasit dihentikan setelah mendapatkan konsentrasi parasit sebanyak 1x10 parasit/ml darah. Penghitungan tingkat parasitemia dilakukan setiap dua hari dengan mengambil sampel darah dari vena ekor, yaitu ujung ekor mencit sedikit dilukai darah yang menetes diambil dengan mikropipet $( \pm 10 \mu \mathrm{l})$, selanjutnya dicampur dengan sds $1 \%$ (1:1) sampai homogen. campuran tersebut diencerkan dengan pbsg dengan perbandingan 1:100 atau 1:1000 sesuai dengan tingkat parasitemianya dan dihitung dengan hemocytometer (naubeuer improved) (Subekti et al. 2013). Pengenceran bertingkat (titrasi) dilakukan untuk mendapatkan 6 level parasitemia yaitu $10^{6}, 10^{5}, 10^{4}, 10^{3}, 10^{2}$, $10^{1}, 10^{0,5}$.

\section{Koleksi sampel darah sapi/kerbau dari lapang}

Sebanyak 41 sampel darah sapi dan kerbau yang diperoleh dari Kabupaten Lebak Provinsi Banten. Sampel darah dikoleksi dalam tabung vacutainer yang mengandung heparin. Sampel darah selanjutnya dibagi menjadi dua bagian untuk pemeriksaan mikroskopis MHCT, ulas darah tipis dan PCR.

\section{Pembuatan preparat ulas darah tipis}

Pembuatan preparat ulas darah tipis dilakukan pada darah heparin segera setelah pengambilan darah. Sebanyak 5 mikroliter darah diteteskan pada seperempat ujung gelas obyek selanjutnya diapus dengan gelas obyek yang lain dengan sudut kemiringan $45^{\circ} \mathrm{C}$. 
Setelah ulas darah kering, selanjutnya dilakukan fiksasi dengan methanol absolut dan pengecatan Giemza 10\% (OIE Terrestrial Manual 2012). Preparat selanjutnya diamati dibawah mikroskop binokuler dengan perbesaran 1000x.

\section{Mikrohematokrit Centrifugation Test (MHCT)}

Tabung mikrohematokrit diisi darah hepain sebanyak $70 \mathrm{ml}$ selanjutnya disenrifugasi pada $12.000 \mathrm{rpm}$ selama 5 menit. Tabung kapiler kemudian diamati dibawah mikroskop binokuler pada bagian buffy coat dengan perbesaran 400x (Terrestrial Manual 2012).

\section{Ekstraksi DNA}

Ekstraksi DNA genom Trypanosoma sp dilakukan dengan sampel darah mencit dan darah sapi/kerbau menggunakan Genomic DNA Mini Kit (Geneaid, Taiwan) sesuai prosedur yang diperoleh dari pabrikan. Hasil ekstraksi DNA masing-masing isolat dimasukkan ke dalam Eppendorf 1,5 mL dan diberi label, kemudian disimpan pada $-20^{\circ} \mathrm{C}$ sampai digunakan untuk analisis lebih lanjut.

\section{Primer yang digunakan, amplifikasi DNA dan visualisasi}

Sebanyak 4 pasang primer digunakan dalam penelitian ini yaitu ESAG 6/7, ITS-1, TR 3/4 dan TBR 2/3 masing-masing mengamplifikasi fragmen sepanjang 740 bp, 470 bp, 164 bp dan 257 bp (Tabel 1). Amplifikasi PCR dilakukan dengan menggunakan Biorad termal cycler (Bio-Rad Laboratories). Amplifikasi primer dilakukan menggunakan My Taq ${ }^{\mathrm{TM}}$ HS DNA Polymerase kit (Bioline, UK) yang terdiri dari My taq reaction buffer sebanyak 12,5 $\mu \mathrm{l}$; My Taq HS DNA polymerase 0,5 $\mu$, Primer forward dan reverse $(10 \mu \mathrm{M})$ masing-masing sebanyak $2 \mu \mathrm{l}$; DNA template (50-100ng) sebanyak $2 \mu \mathrm{l}$ dan PCR grade water 12,5 $\mu \mathrm{l}$ dengan total volume reaksi $25 \mu \mathrm{l}$. Kondisi PCR yang digunakan adalah denaturasi awal $95^{\circ} \mathrm{C}$ selama 3 menit sebanyak 1 siklus diikuti 35 siklus dengan denaturasi $95^{\circ} \mathrm{C}$ selama 30 detik, annealing $56^{\circ} \mathrm{C}$ selama 30 detik, ekstensi $72^{\circ} \mathrm{C}$ selama 30 detik serta ekstensi terakhir $72^{\circ} \mathrm{C}$ selama 10 menit. Produk PCR divisualisasi dengan elektroforesis pada gel agarosa $2 \%$.

Tabel 1. Susunan primer, sekuense dan panjang fragmen yang dihasilkan

\begin{tabular}{|c|c|c|c|}
\hline Nama & Referensi & Urutan basa & $\begin{array}{c}\text { Ukuran } \\
\text { amplikon } \\
\text { (bp) }\end{array}$ \\
\hline ITS-1 & $\begin{array}{l}\text { (Njiru et al. } \\
\text { 2005) }\end{array}$ & $\begin{array}{l}\mathrm{F}: 5 ` C C G G A A G T T C A C C G A T A T T G-3 ` \\
\text { R :5`-TGCTGCGTTCTTCAACGAA-3` }\end{array}$ & 480 \\
\hline $\begin{array}{l}\text { ESAG6/ } \\
7\end{array}$ & $\begin{array}{l}\text { (Isobe et al. } \\
\text { 2003). }\end{array}$ & $\begin{array}{l}\text { F:5’-CATTCCAGCAGGAGTTGGAGG-3’ } \\
\text { R :5’-TTGTTCACTCACTCCTCTTTGACAG-3' }\end{array}$ & 740 \\
\hline TR3/4 & $\begin{array}{l}\text { (Wuyts et } \\
\text { al. 1994) }\end{array}$ & $\begin{array}{l}\text { F : 5’-GCGCGGATTCTTTGCAGACGA-3' } \\
\text { R: 5’-TGCAGACACTGGAATGTTACT-3' }\end{array}$ & 257 \\
\hline TBR1/2 & $\begin{array}{l}\text { (Masiga et } \\
\text { al. 1992) }\end{array}$ & $\begin{array}{l}\text { F :5’-GAA TAT TAA ACA ATG CGC AG-3' } \\
\text { R: 5’-CCA TTT ATT AGC TTT GTT GC-3' }\end{array}$ & 164 \\
\hline
\end{tabular}




\section{HASIL DAN PEMBAHASAN}

Polymerase Chain Reaction dilakukan pada DNA T. evansi yang berasal dari darah mencit yang diinfestasi secara buatan menggunakan 4 pasang primer spesifik ESAG 6/7, ITS-1, TBR 1/2 dan TR3 /4 yaitu masing-masing mengamplifikasi fragmen sepanjang 740 bp, 470 bp, 164 bp dan 257 bp. Setiap set primer diketahui spesifik terhadap $T$. evansi karena tidak mengamplifikasi DNA parasit lain dalam sampel darah. Namun demikian setiap set primer mempunyai sensitivitas yang berbeda dalam mendeteksi $T$. evansi.

Hasil penelitian menunjukkan bahwa deteksi T. evansi dengan PCR menggunakan primer yang spesifik menunjukkan hasil yang lebih sensitif dibandingkan metode konvensional ulas darah tipis maupun mikrohematokrit centrifugation technic (MHCT) (Tabel 2). Hasil pengamatan PCR pada pengenceran bertingkat darah mencit yang diinfeksi secara buatan dengan $T$. evansi diperoleh hasil limit deteksi primer ESAG 6/7 adalah 10 (20\%) -100 (80\%) trypanosoma per ml yaitu sebanyak 80\% dari pengulangan uji menunjukkan limit deteksi $\leq 100$ trypanosom per ml, $20 \%$ pengulangan memiliki limit deteksi $\leq 10$ trypanosoma per ml. Primer ITS-1 menunjukkan limit deteksi $\geq 100$ trypanosoma per $\mathrm{ml}(80 \%)$. Limit deteksi TBR1/2 adalah $\leq 10$ dan $\leq 3$ trypanosoma per ml: $60 \%$ dari pengulangan uji menunjukkan limit deteksi $\leq 10$ trypanosoma per ml, $20 \%$ memiliki limit deteksi $\leq 3$ trypanosoma per ml. Limit deteksi TR 3/4 adalah juga antara $\leq 10$ dan $\leq 3$ trypanosoma per ml tetapi mempunyai persentase yang lebih tinggi dari TBR $1 / 2$ yaitu sebanyak $80 \%$ pengulangan memiliki limit deteksi $\leq 10$ trypanosoma/ml dan $40 \%$ memiliki limit deteksi $\leq 3$ trypanosoma/ml sedangkan TBR $1 / 2$ masing-masing sebanyak $40 \%$ memiliki limit deteksi $\leq 10$ dan $20 \%$ memiliki limit deteksi $\leq 1$ trypanosoma $/ \mathrm{ml}$.

Hasil PCR dengan primer TBR 1/2 menunjukkan terbentuk beberapa pita, namun demikian untuk sampel positif T. evansi selalu teramplifikasi pita berukuran 164 bp (Gambar 1). Hasil tersebut diatas adalah mirip dengan hasil penelitian sebelumnya yang dilakukan oleh Pruvot et al. (2010) bahwa limit deteksi TBR 1/2 antara 10 dan kurang dari 1trypanosoma per $\mathrm{ml}$ (100\% ulangan menunjukkan limit deteksi $\leq 10$ trypanosoma per $\mathrm{ml}, 50 \%$ ulangan menunjukkan limit deteksi $\leq 1$ trypanosoma per ml serta $25 \%$ ulangan menunjukkan limit deteksi dibawah 1 trypanosoma/ml). Sedangkan ESAG 6/7 mempunyai limit deteksi 50 trypanosoma per ml lebih rendah dari hasil penelitian kami. Menurut (Pruvot et al. 2010) banyak faktor yang mempengaruhi sensitivitas deteksi dengan PCR antara lain metode isolasi DNA dan preparasi sampel. Menurut Pruvot et al. (2010) primer TBR 1/2 ini merupakan primer standar emas pengujian untuk deteksi DNA trypanozoon oleh PCR. Hasil elektroforesis gel yang dilakukan dengan keempat primer tersebut juga menunjukkan pita spesifik (Gambar 1). Ulas darah tipis pada darah mencit yang diinfestasi T. evansi hanya mampu mendeteksi parasit dengan konsentrasi terendah $10^{5}(100 \%)$ trypanosoma/ml darah sedangkan MHCT pada $10^{4}(100 \%)$ trypanosome $/ \mathrm{ml}$ darah. Polymerase Chain Reaction menggunakan primer ESAG 6/7, ITS-1, TR3 /4 dan TBR 1/2 dapat mendeteksi T. evansi pada konsentrasi yang lebih kecil yaitu antara $10^{0,5}$ $10^{3}$ trypanosoma $/ \mathrm{ml}$ darah. 
ESAG 6/7 :740 bp

ITS $1 / 2: 470$ bp

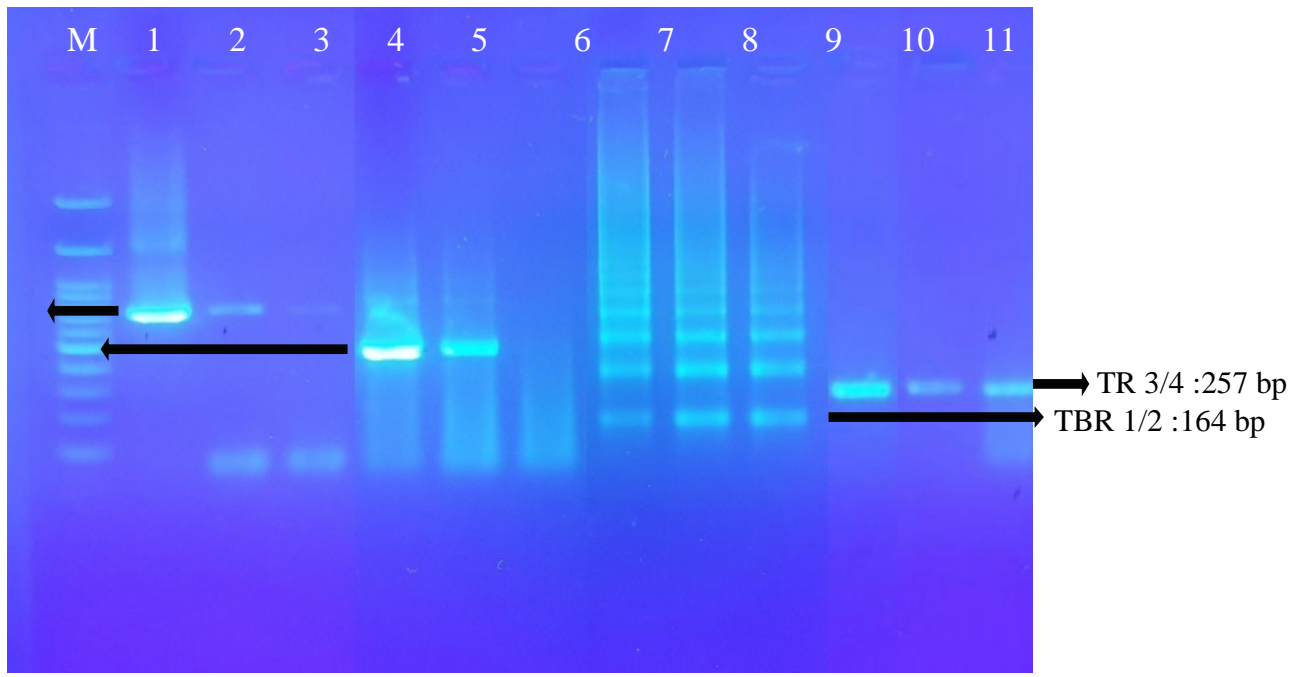

Gambar 1. Hasil PCR kontrol (T.evansi $10^{6}$ parasit/ml darah) dan sampel lapang (darah kerbau Btn 11 dan Btn 12). M: Marker 100 bp. Hasil PCR dengan primer ESAG6/7 (740 bp) lajur 1-3 (1: kontrol; 2: Btn 11; 3: Btn 12); ITS-1 (470bp) lajur 4-6 (4: kontrol; 5: Btn 11; 6: Btn12); TBR1/2 (164bp) Lajur 7-9 (7: kontrol; 8: Btn 11; 9: Btn12); TR3/4 (257 bp) lajur 10-12(10: kontrol; 11: Btn 11; 12: Btn12)

Tabel. 2. Hasil pengujian sampel darah mencit yang diinfestasi $T$. evansi dengan pengenceran bertingkat berdasarkan uji parasitological dan PCR dengan empat primer yang berbeda

\begin{tabular}{|c|c|c|c|c|c|c|c|}
\hline \multirow{3}{*}{$\begin{array}{l}\text { Konsentrasi } \\
\text { pengenceran } \\
T \text {. evansi } \\
\text { pada darah } \\
\text { mencit }\end{array}$} & \multirow{3}{*}{$\begin{array}{l}\text { Jumlah } \\
\text { ulangan }\end{array}$} & \multicolumn{6}{|c|}{ Persentase sampel Positif } \\
\hline & & \multirow{2}{*}{$\begin{array}{c}\text { Ulas } \\
\text { darah } \\
\text { tipis }\end{array}$} & \multirow[b]{2}{*}{ MHCT } & \multicolumn{4}{|c|}{ PCR } \\
\hline & & & & ITS-1 & ESAG6/7 & TR3/4 & TBR1/2 \\
\hline $10^{6}$ & 5 & $100 \%$ & $100 \%$ & $100 \%$ & $100 \%$ & $100 \%$ & $100 \%$ \\
\hline $10^{5}$ & 5 & $100 \%$ & $100 \%$ & $100 \%$ & $100 \%$ & $100 \%$ & $100 \%$ \\
\hline $10^{4}$ & 5 & $0 \%$ & $100 \%$ & $100 \%$ & $100 \%$ & $100 \%$ & $100 \%$ \\
\hline $10^{3}$ & 5 & $0 \%$ & $0 \%$ & $100 \%$ & $100 \%$ & $100 \%$ & $100 \%$ \\
\hline $10^{2}$ & 5 & $0 \%$ & $0 \%$ & $80 \%$ & $80 \%$ & $100 \%$ & $100 \%$ \\
\hline $10^{1}$ & 5 & $0 \%$ & $0 \%$ & $0 \%$ & $20 \%$ & $80 \%$ & $60 \%$ \\
\hline $10^{0,5}$ & 5 & $0 \%$ & $0 \%$ & $0 \%$ & $0 \%$ & $40 \%$ & $20 \%$ \\
\hline
\end{tabular}

Hasil pemeriksaan sampel darah kerbau dan sapi asal kabupaten Lebak, Banten dengan PCR menunjukkan bahwa 14,6-48,5\% sampel positif terinfeksi T. evansi. Kendati demikian dengan metode parasitologi konvensional MHCT hanya terdeteksi 2 sampel positif (4,9\%) dan dengan metode preparat ulas darah tipis tidak terdeteksi adanya sampel darah positif $(0 \%)$ Tabel 3 . Ada banyak faktor yang berkontribusi terhadap hasil deteksi metode konvensional yaitu antara lain adalah stadium infeksi parasit. Infeksi surra dapat 
terjadi secara akut dan kronik dimana pada perjalanan penyakit menuju fase kronik parasit menghilang dari peredaran darah dan konsentrasi rendah parasit pada darah tidak dapat terdeteksi dengan metode konvensional (Pereira et al. 1998). Menurut Pruvot et al. (2010) metode PCR lebih sensitif dibanding metode parasitologi konvensional dalam mendeteksi trypanosoma karena dapat mendeteksi kurang dari 1 parasit/mL darah. Hasil ini juga menunjukkan bahwa uji berbasis pcr mampu mendeteksi $T$. evansi dari darah pada fase infeksi akut dan kronis pada semua hewan yang diuji tergantung pada tingkat infeksi pada sampel uji. Menurut (El-Metanaway et al. 2009; Fernándeza et al. 2009) bahwa teknik diagnostik parasitologis konvensional untuk screening awal adanya infestasi trypanosoma pada sapi kurang cocok untuk analisis epidemiologi skala besar. Teknik parasitologi konvensional hanya dapat mendeteksi sampel positif dalam kisaran 5,3-18,57\% di Nigeria (Abenga et al. 2002; Enwezor et al. 2009) dan Afrika (Mamoudou et al. 2006; Merkuria \& Gadissa 2011). Pada penelitian ini menunjukkan sensitivitas PCR pada angka kejadian infeksi trypanosoma dapat bervariasi tergantung primer yang digunakan. Sensitivitas skrining molekuler berdasarkan PCR lebih tinggi dibandingkan deteksi mikroskopis terkait dengan kesulitan mendeteksi parasit dan rendahnya tingkat parasitemia pada infeksi subklinis. Sesuai dengan hasil penelitian yang dilakukan Singh et al. (2004) menunjukkan, PCR menunjukkan tingkat deteksi empat kali lebih tinggi daripada teknik parasitologis dengan beberapa keunggulan utama dibandingkan dengan teknik parasitologis karena sampel tidak harus diproses dalam waktu singkat setelah pengumpulan dan bisa ditunda. Hasil penelitian Wuyts et al. (1994); Njiru et al. (2004) sensitivitas PCR dengan primer TR 3/4 dan ITS-1 masing-masing adalah > 90\%.

Pada studi ini (Tabel 3) hasil PCR sampel lapang positif dengan PCR menggunakan primer TR 3/4 adalah yang paling tinggi yaitu 48,5\% diikuti oleh TBR 1/2, ITS-1 dan ESAG 6/7 yaitu masing masing 34,1\%; 19,5\% dan 14,65\%. Pada Gambar 2 tampak PCR pada 7 sampel darah kerbau asal Bojongleles, Lebak Banten yaitu Banten 1, Banten 2, Banten 3, Banten 4, Banten 5, Banten 6 dan Banten 7 menunjukkan semua sampel positif dengan primer TR 3/4 tetapi dengan primer TBR 1/2 menunjukkan 6 sampel positif (Banten 1-6). Menurut Pruvot et al. (2010) sensitivitas uji PCR tergantung pada primer yang digunakan dan jumlah pengulangan urutan target dalam genom trypanosoma dan teknik ekstraksi yang benar. TR 3/4 dan TBR 3/4 merupkan sekuen nukleotida berulang pada T. evansi. Namun demikian TBR 3/4 seringkali memproduksi beberapa pita non spesifik dibandingkan dengan satu pita spesifik pada amplikifasi DNA T. evansi pada sampel darah hewan yang berbeda (sapi, kerbau, mencit). Dimana untuk primer TR 3/4 selalu memproduksi satu pita spesifik sesuai target $T$. evansi. Dengan demikian amplifikasi dengan primer TR 3/4 pada sampel darah hewan asal Indonesa menjadi lebih sensitif dan spesifik dibanding TBR 1/2. Kondisi ini dapat berbeda dengan sampel darah hewan dari negara lain seperti Sudan yang menghasilkan 1 pita spesifik (Ibrahim et al. 2017).

Pada studi ini deteksi surra dilakukan pada kerbau/sapi di Banten pada musim kemarau sehingga kasus surra adalah rendah didukung oleh kondisi kandang dan padang penggembalaan yang cukup bersih dengan populasi vektor yang minimal. Menurut Desquesnes et al. (2013) lalat (Tabanids dan Stomoxys) sebagai vektor mekanis merupakan jalur transmisi terpenting penularan T. evansi pada ternak. Seekor ternak dengan infestasi lalat tabanid sejumlah 20-30 ekor menunjukkan probabilitas penularan yang signifikan ketika parasitemia diatas $10^{6}$ trypanosoma/ml. Dengan kata lain kejadian transmisi surra secara langsung berhubungan dengan parasitemia dan jumlah lalat di sekitar ternak (Desquesnes et al. 2009). 
Tabel 3. Hasil pengujian sampel darah sapi dan kerbau di kabupaten Lebak, Banten dengan uji parasitological dan PCR dengan empat primer yang berbeda

\begin{tabular}{|c|c|c|c|c|c|c|c|}
\hline \multirow{3}{*}{$\begin{array}{l}\text { Desa, } \\
\text { Kecamatan }\end{array}$} & \multirow{3}{*}{$\begin{array}{l}\text { Jenis } \\
\text { ternak }\end{array}$} & \multirow{3}{*}{$\begin{array}{l}\text { Jumlah } \\
\text { sampel }\end{array}$} & \multicolumn{5}{|c|}{ 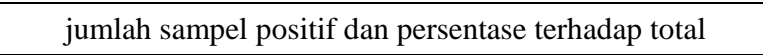 } \\
\hline & & & \multirow[b]{2}{*}{ MHCT } & \multicolumn{4}{|c|}{ PCR } \\
\hline & & & & ITS-1 & $\begin{array}{c}\text { ESAG } \\
6 / 7\end{array}$ & TBR1/2 & TR3/4 \\
\hline $\begin{array}{l}\text { Sukajadi, } \\
\text { Penggarangan }\end{array}$ & Kerbau & 19 & $1(2,4 \%)$ & $4(9,75 \%)$ & $\begin{array}{c}4 \\
(9,75 \%)\end{array}$ & $\begin{array}{c}6 \\
(14,6 \%)\end{array}$ & $\begin{array}{c}8 \\
(19,5 \%)\end{array}$ \\
\hline $\begin{array}{l}\text { Tamansari, } \\
\text { Banjarsari }\end{array}$ & Sapi PO & 10 & $0(0 \%)$ & $0(0) \%)$ & $0(0 \%)$ & $0(0 \%)$ & $0(0 \%)$ \\
\hline \multirow[t]{2}{*}{$\begin{array}{l}\text { Bojongleles, } \\
\text { Cibadak }\end{array}$} & Kerbau & 12 & $1(2,4 \%)$ & $2(4,9 \%)$ & $\begin{array}{c}4 \\
(9,75 \%)\end{array}$ & $\begin{array}{c}8 \\
(19,5 \%)\end{array}$ & $12(29 \%)$ \\
\hline & Total & 41 & $2(4,9 \%)$ & $\begin{array}{c}6 \\
(14,65 \%)\end{array}$ & $\begin{array}{c}8 \\
(19,5 \%)\end{array}$ & $\begin{array}{c}14 \\
(34,1 \%)\end{array}$ & $\begin{array}{c}20 \\
(48,5 \%)\end{array}$ \\
\hline
\end{tabular}

Dengan demikian $T$. evansi di Banten hampir tidak terdeteksi dengan metode konvensional atau dalam artian konsentrasi $T$. evansi adalah rendah atau sangat rendah pada sirkulasi darah tepi. TR 3/4 dan TBR 1/2 mempunyai sensitivitas yang mirip dan lebih tinggi dibandingkan 2 primer yang lain yaitu mampu mendeteksi antara $\leq 3-10$ trypanosoma/ml darah. Pada kasus seperti ini sangat dibutuhkan metode deteksi dengan sensitifitas yang tinggi untuk deteksi surra sehingga perencanaan program pengendalian dapat dilakukan dengan tepat pada musim penghujan.

Dengan demikian primer TR 3/4 dan TBR 1/2 dapat digunakan secara rutin untuk surveillance dan studi epidemiologi surra pada daerah endemis untuk deteksi dini hewan resevoar baik pada tahap akut, sub akut, kronis, periode prepaten dan periode pada saat parasit relaps. Sedikit perbedaan limit deteksi dengan penelitian sebelumnya yang dilakukan Pruvot et al. (2010)kemungkinan disebabkan oleh teknik titrasi (pengenceran bertingkat) yang kurang tepat, jumlah sampel, variasi genetik strain, kondisi reaksi, teknik isolasi dna, umur penyimpanan sampel dan sebagainya.

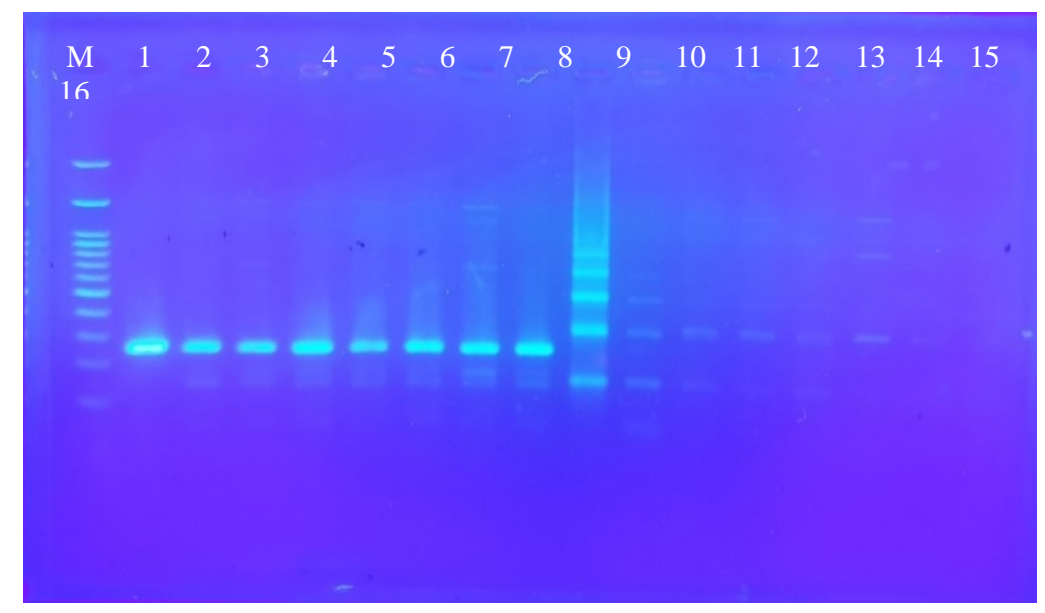

Gambar 2. Hasil PCR sampel DNA darah kerbau asal Lebak Banten dengan primer TR 3/4 (lajur 1-7) dan TBR 1/2 (lajur 10-15). M: marker; 1: Kpos T.evansi $10^{6}$ parasit/ml dengan primer TR 3/4; lajur 2-8 adalah sampel Btn1-Btn 7.Lajur 9 Kpos T. evansi $10^{6}$ parasit/ml dengan primer TBR 1/2: Lajur 10-16 adalah sampel Btn 1-Btn 7 


\section{KESIMPULAN}

Primer TR 3/4 mempunyai sensitivitas tertinggi diikuti primer TBR 1/2 dan 2 primer yang lain yaitu dengan urutan TR 3/4 $\geq$ TBR 1/2 > ESAG 6/7 > ITS-1. Primer ESAG 6/7 dan ITS-1 menunjukkan limit deteksi 100-1000 trypanosoma per ml darah. Primer TR 3/4 dan TBR 1/2 mempunyai limit deteksi antara 10 dan $\leq 3$ trypanosoma per ml darah. Primer ITS-1, ESAG 6/7, TBR 1/2 dan TR 3/4 masing-masing mendeteksi 14,6\%; 19,5\%; 34,1\%; dan 48,5 \% sampel darah kerbau/sapi asal Banten positif T. evansi. Primer TR 3/4 dapat digunakan secara rutin untuk surveillance dan studi epidemiologi surra pada daerah endemis untuk deteksi dini hewan resevoar baik pada tahap akut, sub akut maupun kronis.

\section{UCAPAN TERIMA KASIH}

Penelitian ini dilaksanakan dengan dana APBN T. A. 2019. Penulis mengucapkan terima kasih kepada Bapak Suharyanta dan Sudrajat atas bantuan teknis di laboratorium.

\section{DAFTAR PUSTAKA}

Abenga JN, Enwezor FNG, Lawani FAG, Ezebuiro C, Sule J, David KM. 2002. A prevalence of trypanosomosis in trade cattle at slaughter in Kaduna, Nigeria. Niger J Parasitol. 23:107-111.

Ahmed HA, Picozzi K, Welburn SC, Macleod ET. 2013. A comparative evaluation of PCRBased methods for species- Specific determination of African animal trypanosomes in Ugandan cattle [Internet]. [cited 16 Februari 2019]. 6:1. Available from: Parasites \& Vectors.

Barghash S, Abou El-Naga T, El-Sherbeny E, Darwish A. 2014. Prevalence of 350 Trypanosoma evansi in Maghrabi camels (Camelus dromedarius) in Northern-West Coast, Egypt using molecular and parasitological methods. Acta Parasitol Glob. 5:125132.

Desquesnes M, Biteau-Coroller F, J. Bouyer M, Dia L, Foil L. 2009. Development of a mathematical model for mechanical transmission of trypanosomes and other pathogens of cattle transmitted by tabanids. Int J Parasitol. 39.

Desquesnes M, Dargantes A, Lai D, Lun Z, Holzmuller P, Jittapalapong S. 2013. Trypanosoma evansi and surra: A review and perspectives on transmission, epidemiology and control, impact, and zoonotic aspects. Biomed Res Int [Internet]. [cited 16 Februari 2019]. 2013:1-20. Available from: http://ovidsp.ovid.com/ovidweb.cgi?T=JS\&PAGE=reference \&D=emed11\&NEWS=N\& $\mathrm{AN}=2013652279$.

Desquesnes M, Dávila AMR. 2002. Applications of PCR-based tools for detection and identification of animal trypanosomes: A review and perspectives. Vet Parasitol. 109:213-231.

Desquesnes M, Tresse L. 1996. Evaluation de la sensibilité du test de WOO pour la détection de Trypanosoma vivax. Rev d’élevage Médecine Vétérinaire des Pays Trop. 49:315-321.

El-Metanaway TM, El-Beih NM, El-Aziz MM, Hassanane MS, El-Aziz TH. 2009. Comparative studies on diagnosis of Trypanosoma evansi in experimentally infected goats. Glob Vet. 3:348-353. 
Enwezor FNC, Umoh JU, Esievo KAN, Halid I, Zaria LT, Anere JI. 2009. Survey of bovine trypanosomosis in the Kachia Grazing Reserve, Kaduna state, Nigeria. Veterinary Parasitology. Vet Parasitol. 159.

Fernándeza D, González-Baradata B, Eleizaldea M, González-Marcanob E, Perroneb T, Mendoza M. 2009. Trypanosoma evansi: A comparison of PCR and parasitological diagnostic tests in experimentally infected mice. Exp Parasitol. 121:1-7.

Greiner M, Kumar S, Kyeswa C. 1997. Evaluation and comparison of antibody ELISAs for serodiagnosis of bovine trypanosomosis. Vet Parasitol. 73:179-205.

Holland WG, Claes F, My LN, Thanh NG, Tam PT, Verloo D, Büscher P, Goddeeris B, Vercruysse J. 2001. A comparative evaluation of parasitological tests and a PCR for Trypanosoma evansi diagnosis in experimentally infected water buffaloes. Vet Parasitol. 97:23-33.

Ibrahim H, Croof MN, Malelle I, Brooks D, Abdella HS, Osman N, Ali M. 2017. Molecular isolation and characterization of Trypanosoma evansi in dromedary camels from different regions of Sudan. Am J Microbiol Biotechnol. 4:67-74.

Isobe T, Holmes EC, Rudenko G. 2003. The transferrin receptor genes of Trypanosoma equiperdum are less diverse in their transferrin binding site than those of the broad-host range Trypanosoma brucei. J Mol Evol. 56:377-386.

Juyal PD, Singla LD, Kaur P. 2005. Management of Surra due to Trypanosoma evansi in India: an overview. an overview V Tandon BN Dhawan Infect Dis Domest Anim zoonosis India P Natl A Sci India B. 75:109-120.

Kabiri M, Steverding D. 2001. Identification of a developmentally regulated iron superoxide dismutase of Trypanosoma brucei. Biochem J. 260:173-177.

Kooter J, van der Spek H, Wagter R, D’Oliveira C, van der Hoeven F, Johnson P, Borst P. 1987. The anatomy and transcription of a telomeric expression site for variant-specific surface antigens in T. brucei. Cell. 51:261-272.

Kundu K, Tewari AK, Kurup SP, Baidya S, Rao JR, Joshi P. 2013. Sero-surveillance for surra in cattle using native surface glycoprotein antigen from Trypanosoma evansi. Vet Parasitol. 196:258-264.

Luckins AG. 1992. Protozoal diseases of camels. In: Allen WR, Higgins AJ, Mayhew IG, Snow DH, Wade JF, editors. Proceeding 1st International of Conference RW Publ New Mark Limited. Suffolk (UK). p. 22-27.

M Barghash S, M Darwish A. 2016. Molecular characterization and phylogenetic analysis of Trypanosoma evansi from local and imported camels in Egypt. J Phylogenetics Evol Biol. 4.

Mamoudou A, Zoli A, Mbahin N, Tanenbe CB, Clausen PH, Marcotty T, Van den Bossche P, Geerts S. 2006. Prevalence and incidence of bovine trypanosomosis on the Adamaoua plateau in Cameroon 10 years after the tsetse eradication campaign. Vet Parasitol. 142:16-22.

Masake RA, Njuguna JT, Brown CC, Majiwa PAO. 2002. The application of PCR-ELISA to the detection of Trypanosoma brucei and T. vivax infections in livestock. Vet Parasitol. 105:179-189.

Masiga D, Smyth A, Hayes P, Bromidge T, Gibson W. 1992. Sensitive detection of trypanosomes in tsetse flies by DNA amplification. Int J Parasitol. 22:909-918.

Merkuria S, Gadissa F. 2011. Survey of bovine trypanosomosis and its vector in Metekel and Awi zones of North West Ethiopia. Acta Trop. 117:146-151. 
Njiru N, Constantine C, Guya S, Crowther J, Kiragu J, Thompson R, Dávila A. 2005. The use of ITS1 rDNA PCR in detecting pathogenic African trypanosomes. Parasitol Res. 95:186-192.

Njiru ZK, Constantine CC, Ndung'u JM, Robertson I, Okaye S, Thompson RCA, Reid SA. 2004. Detection of Trypanosoma evansi in camels using PCR and CATT/T. evansi tests in Kenya. Vet Parasitol. 124:187-199.

OIE Terrestrial Manual. 2012. Trypanosoma evansi infection (SURRA). p. 1-15.

Pereira DE, Almeda PJ, Ndao M, Goosens B, Osaer S. 1998. PCR Primer Evaluation for the detection of trypanosoma DNA in naturally infected goats. Vet Parasitol. 80:111-116.

Pruvot M, Kamyingkird K, Desquesnes M, Sarataphan N, Jittapalapong S. 2010. A comparison of six primer sets for detection of Trypanosoma evansi by polymerase chain reaction in rodents and Thai livestock. Vet Parasitol. 171:185-193.

Pruvot M, Kamyingkird K, Desquesnes M, Sarataphan N, Jittapalapong S. 2013. The effect of the DNA preparation method on the sensitivity of PCR for the detection of Trypanosoma evansi in rodents and implications for epidemiological surveillance efforts. Vet Parasitol. 191:203-208.

Salim B, Bakheit MA, Kamau J, Nakamura I, Sugimoto C. 2011. Molecular epidemiology of camel trypanosomiasis based on ITS1 rDNA and RoTat 1.2 VSG gene in the Sudan. Parasit Vectors. 4:31.

Schell D, Borowy NK, Overath P. 1991. Transferrin in a growth factor for the bloodstream form of Trypanosoma brucei. 30:558-560.

Sharma A, Singla L Das, Tuli A, Kaur P, Batth BK, Javed M, Juyal PD. 2013. Molecular prevalence of Babesia bigemina and Trypanosoma evansi in dairy animals from Punjab, India, by duplex PCR: A step forward to the detection and management of concurrent latent infections. Biomed Res Int. 2013.

Singh N, Pathak KML, Kumar R. 2004. A comparative evaluation of parasitological, serological and DNA amplification methods for diagnosis of natural Trypanosoma evansi infection in camels. Vet Parasitol. 126:365-373.

Singla L Das, Sharma A, Kaur P, Tuli A, Bhat SA, Bal S, Angad G, Veterinary D. 2013. Bovine Trypanosomosis in Punjab: Assesment of seroprevalence by CATT/T. evansi. Int J Adv Res. 1:364-371.

Subekti DT, Sawitri DH, Suhardono, Wardhana AH, DH S, AH W. 2013. Pola parasitemia dan kematian mencit yang diinfeksi Trypanosoma evansi isolat Indonesia. JITV. 18:274290.

Terrestrial Manual O. 2012. Trypanosoma evansi infections (including surra). OIE Terr Manual. p. 1-4.

Wuyts N, Chokesajjawatee N, Panyim S. 1994. A simplified and highly sensitive detection of Trypanosoma evansi by DNA amplification. Southeast Asian J Trop Medic Public Heal. 25:266-271. 